\title{
CROESUS AND THE ORACLES
}

\author{
PETER THONEMANN \\ University of Oxford*
}

\begin{abstract}
Herodotus' narrative of the testing of various Greek oracles by King Croesus of Lydia (1.46-54) has long been viewed with justifiable scepticism. A newly published verse dedication from the sanctuary of Apollo Ismenios at Thebes (Papazarkadas 2014: 233-48) sheds welcome light on Herodotus' sources for this part of his Croesus-narrative. Herodotus' account of Croesus' testing of the oracle of Amphiaraus at Thebes appears to have been an imaginative extrapolation from the text of this inscription. But there is good reason to believe that Herodotus significantly misinterpreted the historical context and significance of the epigraphic text he had before him; in particular, the real author of the dedication is unlikely to have been King Croesus of Lydia, and may instead have been an Athenian aristocrat of the Alcmaeonid family. The new inscription from Thebes sheds light both on Herodotus' use of documentary evidence and on the creative misreading of early epigraphic texts by Theban sanctuary personnel in the mid fifth century BC.
\end{abstract}

Keywords: Croesus, Herodotus, Boeotia, epigraphy, oracles

\section{Herodotus and Croesus}

In the first book of his Histories, Herodotus gives a vivid narrative of the last years of the reign of King Croesus of Lydia ( $c a$. 585-547/6 BC). ${ }^{1}$ Upon learning of the rise of the Persian Empire in the east, Croesus sent envoys to all the major oracles of the Greek world, in order to find out which of them had genuine access to the mind and will of the gods (1.46). On a fixed day, each oracle was asked simply: 'What is Croesus son of Alyattes, king of the Lydians, doing at this moment?'. Most oracles failed the test; but the Delphic Oracle correctly pronounced that Croesus was cooking a tortoise and a lamb in a bronze cauldron (1.47-48). Herodotus goes on (1.49):

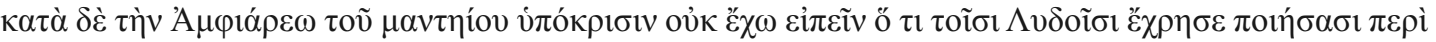

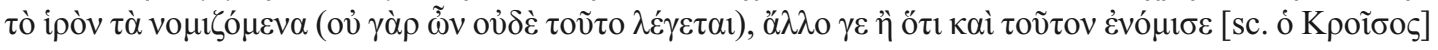

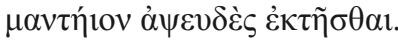

I cannot say what answer the oracle of Amphiaraus gave to the Lydians once they had performed the traditional rites at the sanctuary, for there is no record of it; I only know that Croesus also thought that this too was a truthful oracle.

Croesus then offered lavish sacrifices and dedications of gold and silver to Delphic Apollo, in order to make the god favourable to his cause (1.50-51). Amphiaraus, too, received a notable votive offering from Croesus, a golden shield and spear, which were seen by Herodotus a century later in the sanctuary of Apollo Ismenios at Thebes (1.52):

* peter.thonemann@wadh.ox.ac.uk. I am grateful to Paul Cartledge, Peter Green, David Harvey and two anonymous JHS referees for their acute criticisms. I also benefited from the comments of seminar audiences in Oxford and St Andrews. My greatest debt is to Nikolaos Papazarkadas, for long and fruitful discussion of the inscription republished here. A shorter version of this paper was published as 'Evidence of Gold' in the Times Literary Supplement, 15 August 2014, 14-15.

\footnotetext{
1 The traditional date ( 547 or 546 BC) for the Persian conquest of Lydia is probably correct: van der Spek (2014) 256 n.184 (contra Rollinger (2008)). For the length of Croesus' reign (and an accession date in the mid 580s), see Robert W. Wallace's convincing arguments (2016). For archaeological evidence for the sack of Sardis, see Cahill (2010).
} 


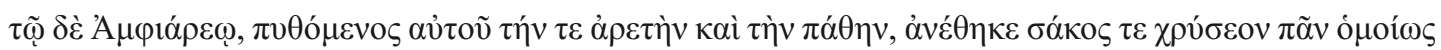

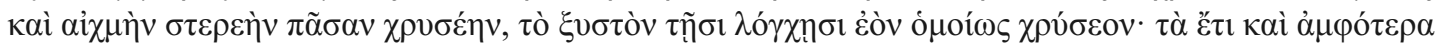

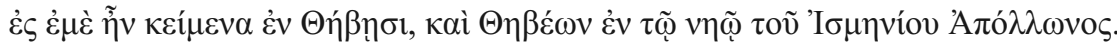

And as for Amphiaraus, once Croesus had learned of his virtue and his suffering, he dedicated to him a shield made entirely of gold, and a spear of solid gold from its shaft to its tip. In my own day, both of these were still located at Thebes, in the Theban sanctuary of Apollo Ismenios.

Croesus went on to ask the oracles of Apollo and Amphiaraus whether he ought to risk war with the Persians. Both oracles replied that if he did so, he would destroy a mighty empire. Emboldened by this, Croesus marched east into Cappadocia, where he met the army of Cyrus. The battle (near the site of Pteria, perhaps modern Kerkenes Dağ) was indecisive, and Croesus withdrew to Sardis. The city fell to the Persians after a fortnight's siege, and as the defeated Croesus was led to the pyre on which he was to be burned alive before the Persian king, the truth of the oracles at last became clear to Croesus. He had indeed destroyed a mighty empire: his own.

Most modern critics have treated Herodotus' account of Croesus' relations with the Greek oracles of Apollo and Amphiaraus with some scepticism. The list of seven oracles said to have been tested by Croesus is idiosyncratic (1.46), and the whole notion of oracular 'testing' runs into serious practical difficulties. ${ }^{2}$ Although it was normal enough for consultants to seek to verify or explicate the content of a particular oracular response, there are no historical parallels for this kind of experimental vetting of a Greek oracle's reliability. ${ }^{3}$ Nonetheless, there is no reason to doubt that Herodotus did indeed see a lavish group of dedications offered by Croesus at Delphi (1.5051). Herodotus' descriptions of these objects are precise and circumstantial; some of the details of his account (in particular the weights of gold and silver) could well derive from official Delphic inventory lists and certain objects may even have been inscribed with Croesus' name. ${ }^{4}$ Similarly, we have no good reason to doubt the existence of the golden shield and spear dedicated to Amphiaraus at the sanctuary of Apollo Ismenios (1.52). But that is not to say that Herodotus describes the historical context of these various dedications correctly.

Amidst the various implausibilities of Herodotus' account of Croesus and the Greek oracles, I would like to highlight one particular oddity. In his original account of Croesus' oracular tests (1.46-54.1), Herodotus is quite clear that Croesus believed that two Greek oracles, those of Apollo at Delphi and Amphiaraus at Thebes, were authentic. Both oracles are consulted on the propriety of making war on Persia and both are said to have given the same, two-edged response. But at this point, the oracle of Amphiaraus quietly drops out of the story. Croesus' gratitude for this second oracular response is directed at the Delphians alone (1.54.2); his third enquiry, on the future duration of his reign, was made of Delphic Apollo alone (1.55-56). Later, after the fall of Sardis, when Croesus recalls his earlier oracular consultations, it is, once again, only the oracle of Delphi which comes into question $(1.87,1.90-91)$.

In purely narrative terms, the presence of Amphiaraus as a second true oracle clearly causes Herodotus some problems. In his original report of Delphi's successful response to Croesus' test, Herodotus says that Croesus 'considered that the oracle at Delphi was the only true one, because

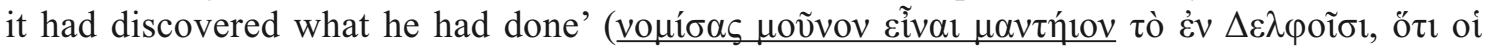

2 Apollo at Delphi, Apollo at Abai, Zeus at Dodona, Amphiaraus at Thebes, Trophonius at Lebadeia, Apollo at Branchidae, Zeus Ammon in Libya. Implausibilities: Asheri et al. (2007) 108-09. On oracular testing more generally, see Bonnechere (2010). For the location of the oracle of Amphiaraus, see further below.

3 Hdt. 8.133-35 (Mardonius' oracular consultations in $479 \mathrm{BC}$ ) is not a precise analogy. Xen. Cyr. 7.2.17 highlights the moral absurdity of Croesus' testing.

\footnotetext{
${ }^{4}$ Flower (1991) 66-70; Mills (2014). Inventory lists: Kosmetatou (2013). Inscriptions: Fabiani (2003) 157-58. The 'conventional' capacity of Croesus' silver kratêr at 1.51.2 (600 amphorae) is rightly questioned by Fehling (1989) 223-24; but there is no reason to suspect the specified weight of the 'gold' krater referred to in the same passage: eight talents and a half plus 12 minae (on this object, see further n.38 below).
} 


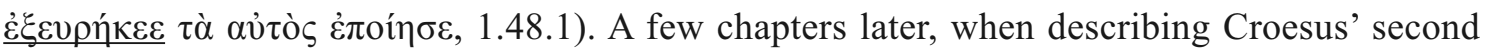
enquiry, about his proposed war with Persia, Herodotus uses almost exactly the same phraseology, but this time in the plural: 'considering that these [i.e. the oracles of Apollo and Amphiaraus] are

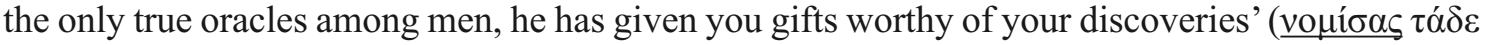

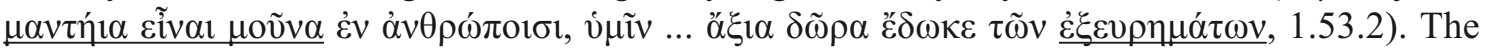
common phraseology might suggest that Herodotus was drawing on a written text of some kind, conceivably an inscribed dedication at Delphi. ${ }^{5}$ At any event, the awkward shift from singular to plural - one true oracle or two true oracles? - clearly indicates that Herodotus was trying to reconcile two incompatible traditions. ${ }^{6}$

What, we might wonder, is Amphiaraus doing in Herodotus' account at all? Herodotus must surely have had more to go on than the bare survival of a dedication of Croesus to Amphiaraus at the sanctuary of Apollo Ismenios (1.52). After all, Croesus also set up lavish dedications to the oracular Apollo of Branchidae (1.92.2), a god who had no success in the story of Croesus' testing of the oracles. ${ }^{7}$ It is reasonable to assume that Herodotus saw or heard something at the sanctuary of Apollo Ismenios to convince him that Amphiaraus had also passed Croesus' test, and that he tried - awkwardly and inconsistently - to incorporate this 'fact' into his account of Croesus' special relationship with Delphi. And thanks to a spectacular new monument from Thebes, we now know precisely what this 'something' was.

\section{Croesus and Amphiaraus: new evidence}

In 2005, rescue excavations in the modern town of Thebes turned up a battered column drum of micaceous poros stone, bearing two fragmentary inscriptions on opposite sides of the column. These inscriptions have recently been published, with a full and meticulous commentary, by Nikolaos Papazarkadas. ${ }^{8}$ The earlier of the two texts (Text A) runs vertically along the length of the column from top to bottom, is cut in a local Boeotian Greek script and is dated by Papazarkadas to the late sixth or early fifth century BC (fig. 1). The later text (Text B), apparently of the fourth century BC, uses the Ionic Greek alphabet and runs horizontally across the width of the column. Both inscriptions are fragmentary and carry overlapping parts of the same eight-line verse epigram; aside from the orthographic differences that come with the use of two different scripts, the content of the two texts seems to have been identical.

The earlier inscription (Text A), in Boeotian script, preserves the beginnings of eight lines of elegiac verse (four elegiac couplets), with each line of the inscription corresponding to a single verse. Roughly half of each verse survives, with two or three letters missing at the start of each line (i.e. at the top of the column drum, since the inscription runs vertically top to bottom). The lower end of the column seems to be intact - Papazarkadas describes it as 'hewn' - and the original inscription presumably continued onto a second column drum below. Text B consists of eight fragmentary and badly-worn lines in Ionic script, this time running horizontally across the face of the stone. The lines of Text B are much shorter than those of Text A, and the mason has made no attempt to make the lines correspond to the verses of the epigram. Text B preserves parts of verses 1-5 of the epigram (verses 6-8 presumably being inscribed on a second, lower column drum); there are substantial overlaps with the surviving parts of Text A.

I first present the original (and better-preserved) Boeotian text, Text A, accompanied by full apparatus criticus and translation. Many of the restorations in verses 1-4 are guaranteed by surviving parts of the Ionic text, Text B; these parts are indicated by underlining. My printed text (based on Papazarkadas' excellent editio princeps) is relatively conservative, although the reader should note that my translation incorporates several further textual suggestions (in verses 1, 3 and

5 Kosmetatou (2013) 74 (over-confident).

${ }^{6}$ Hellmann (1934) 71-73; Flower (1991) 64; Christ (1994) 189.
${ }^{7}$ Kerschner (2006) (overview of Lydian votives in Greek sanctuaries).

8 Papazarkadas (2014) 233-48. 


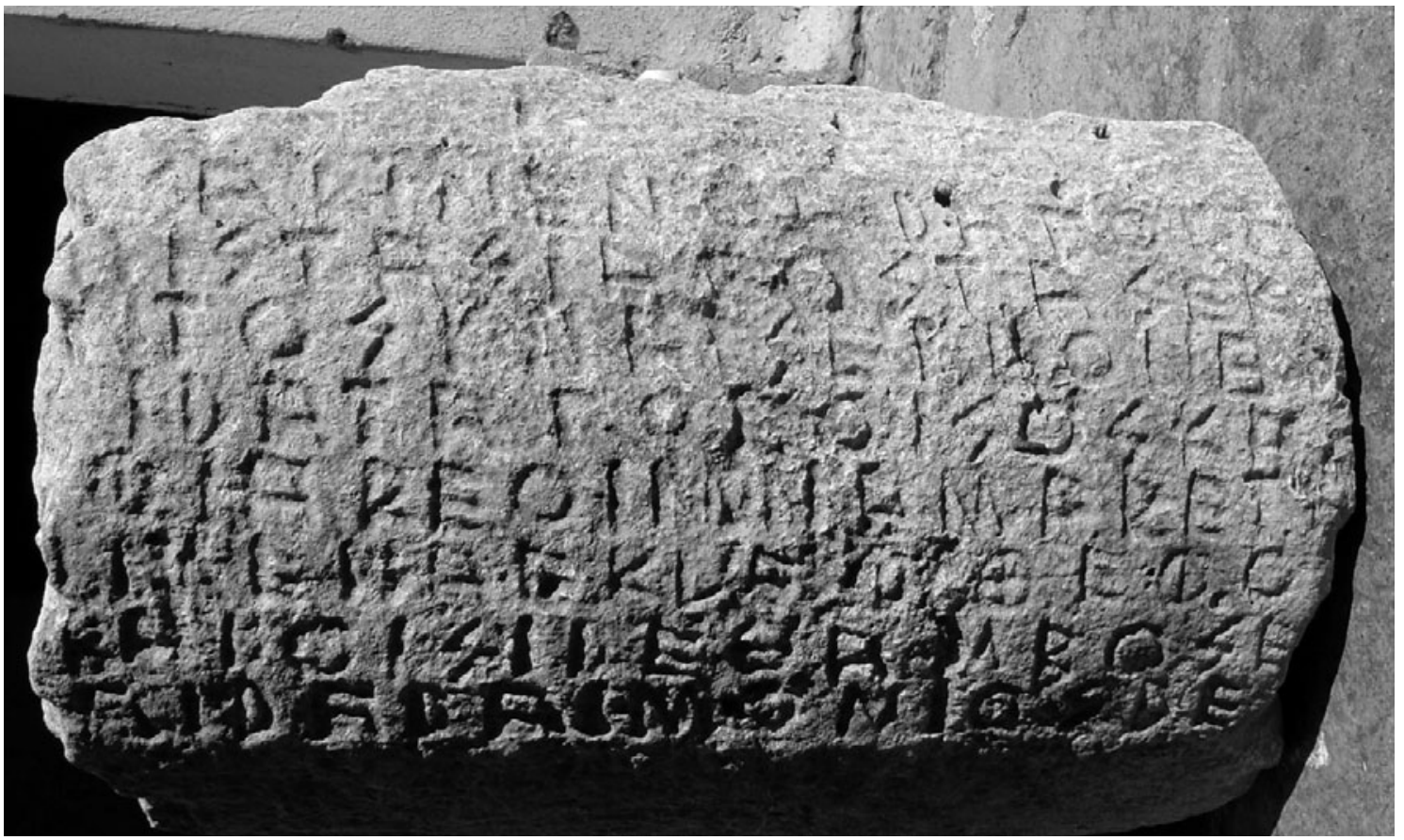

Fig. 1. Inscribed dedication from the sanctuary of Apollo Ismenios at Thebes, Text A, ca. 500 BC (Papazarkadas (2014) 234, fig. 3; photo courtesy of Nikolaos Papazarkadas).

4), all presented in the apparatus criticus and fully discussed in the line-by-line commentary below. I then present the Ionic Text B separately. The published photograph of this face of the stone is very difficult to read, and my text is heavily dependent on the transcription offered by Papazarkadas in the editio princeps.

Text A

Boeotian script, $c a$. 525-475 BC:

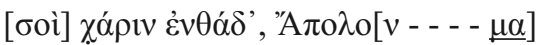

$[\theta \varepsilon \sigma] \pi \imath \sigma \tau \dot{\alpha} \varsigma$ i $\alpha \rho \tilde{o} \sigma \tau \tilde{\alpha} \sigma \varepsilon \kappa[\underline{\alpha \tau \varepsilon v \chi \sigma \alpha ́} \underline{\mu \varepsilon v o \varsigma,]}$

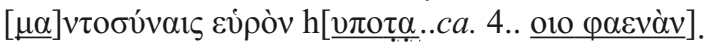

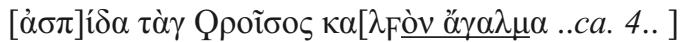

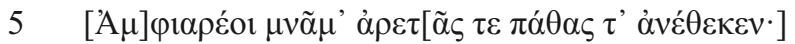

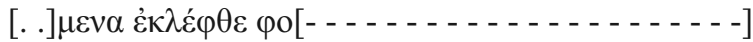

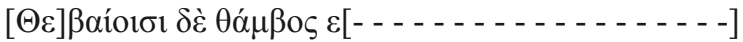

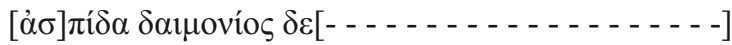

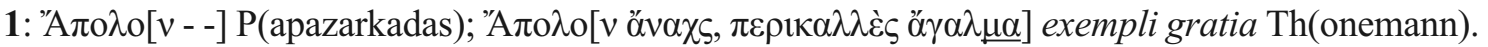

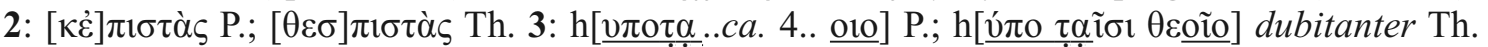

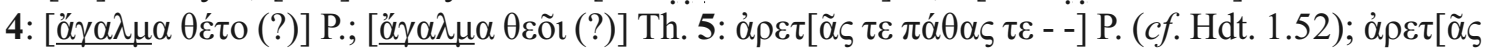
$\left.\tau \varepsilon \pi \alpha \dot{\theta} \theta \varsigma \tau^{\prime} \dot{\alpha} v \varepsilon \dot{\theta} \theta \varepsilon \kappa \varepsilon v\right] \mathrm{Th}$.

Translation: 'As a thank-offering [to you, (?) lord] Apoll[o], the [pro]phet of the sanctuary set up [(?) this most beautiful ornament] here in ful[filment of a v]ow, having found through oracular consultation [of the god] the shining shield which Croesus [dedicated] as a beautiful ornament to [...] Amphiaraus, a memorial of his virt[ue and suffering;] ... was stolen (?) ... a marvel to the Thebans ... [the sh]ield, wondrously ...' 
Text B

Ionic script, ca. 400-350 BC:

$[\ldots] \mathrm{MA} \cdot / \theta \underline{\theta}[\varepsilon \sigma \pi 1 \sigma \tau \alpha \grave{s}$ i $i \rho \rho]-$

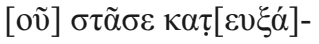

$\mu \varepsilon v o \zeta / \mu \alpha v \tau \sigma o ̛ ̣\left[v v^{\prime} \alpha u\right]-$

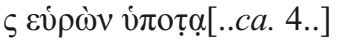

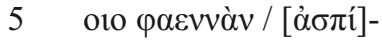

$\delta \alpha \tau \grave{\alpha} v \Gamma \rho 0 \tilde{[}[\sigma o \zeta \kappa \alpha \lambda]-$

òv $\alpha$ $\gamma \alpha \lambda \mu[\alpha$..ca. 4.. / А $\mu \varphi 1]-$

$\alpha \rho \varepsilon ́ \omega 1[----]$

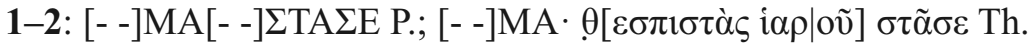

Verse 1. For the invocation of the deity in the vocative, Papazarkadas compares CEG 336 (a late

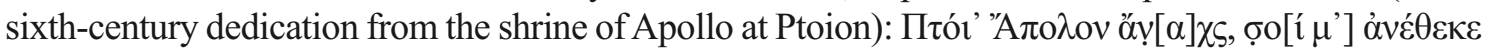

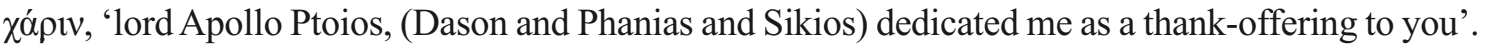
The term $\dot{\varepsilon} \theta \theta \alpha \dot{\delta} \varepsilon$, 'here', is very common in Archaic votive monuments: $c f$., for example, CEG 234

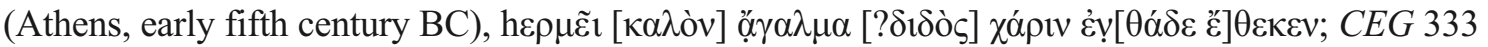

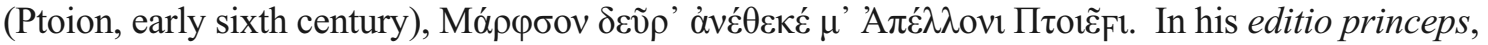
Papazarkadas ((2014) 240) assumes that the name of the re-dedicant (the [thes]pistas of verse 2) was given at the end of verse 1. However, we need to take into account the two legible letters ( $m u$ alpha) in the first line of Text B. These two letters must have stood at the very end of verse 1 of the epigram; indeed, the layout of Text B makes it all but certain that the last word of verse 1 ended $-\mu \alpha$. A patronym in the genitive (of a name in - $\mu \alpha \varsigma$ ) is conceivable, but it is surely easier to restore here the

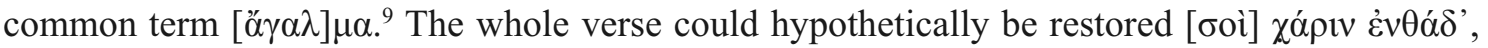

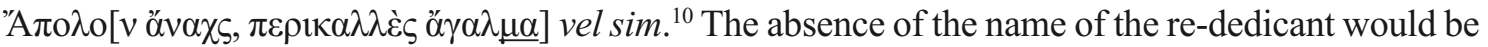
a little surprising, but the description of his office ( $[\theta \varepsilon \sigma] \pi 1 \sigma \tau \grave{\alpha} \varsigma$ i $\alpha \rho \tilde{o}$, verse 2$)$ may have been thought to suffice - after all, the dedication itself was due to Croesus, not to the Theban [thes]pistas. Alternatively, the re-dedicant's name could perhaps have been given in the lost second part of verse 8 .

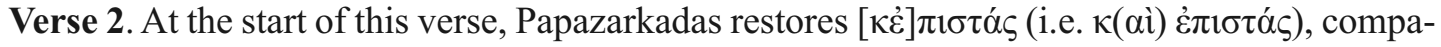
ring (for the crasis) SEG 56.521 (Thebes, ca. 506 BC): ḥє to see what function the $\kappa(\alpha i)$ could be serving here. Papazarkadas ((2014) 240) suggests that a second office or title held by the re-dedicant could have appeared in the missing part of verse 1 , but, as we have already seen, the letters surviving at the end of the verse $(-\mu \alpha)$ make this rather

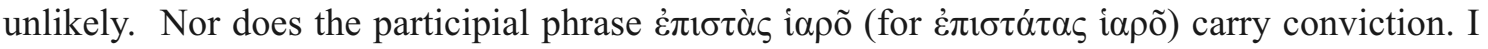
hence prefer to restore here $[\theta \varepsilon \sigma] \pi \imath \sigma \tau \alpha \alpha_{\varsigma}$, 'prophet'. The term $\theta \varepsilon \sigma \pi \imath \sigma \tau \eta \dot{\varsigma}$ is very rare: it appears first in a fragment of the Homerizing epic On Jerusalem by the elder Philo (second century BC). ${ }^{11}$

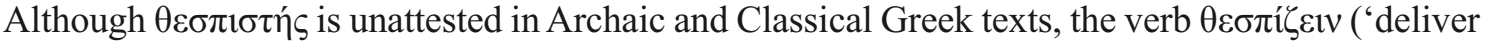
an oracle') and the noun $\theta \dot{\varepsilon} \sigma \pi \imath \sigma \mu \alpha$ ('oracular response') are both common enough in fifth-century Greek; Herodotus twice uses $\theta \varepsilon \sigma \pi i$ '́ctv in book 1 of the various oracles' responses to Croesus'

9 A dedication from the Ptoion (ca. $500 \mathrm{BC})$ was

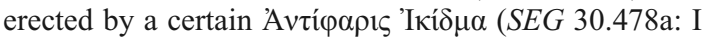
owe the reference to Albert Schachter).

10 The phrase $\pi \varepsilon \rho \iota \kappa \alpha \lambda \lambda \grave{\varepsilon} \varsigma$ $\alpha \gamma \alpha \lambda \mu \alpha$ appears at line-end in two of the three dedications from the sanctuary at Apollo Ismenios recorded by Herodotus in 5.59-61; cf. also CEG 335 (sanctuary of Apollo Ptoios, ca. 550-500
BC: $\pi \varepsilon \rho \iota \kappa \alpha \lambda \delta \grave{\varepsilon} \varsigma \not ̊ \alpha \gamma[\alpha \lambda \mu \alpha]$ ); CEG 363 (Argos, late seventh century); CEG 422-23 (IG XII 6.2 558C-D: Samos, ca. 570-560 BC).

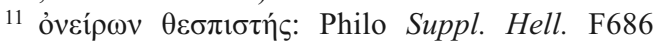
(quoted by Euseb. Hist. eccl. 9.24). The usual Greek terms for a prophet are $\pi \rho \circ \varphi \eta ́ \tau\rceil \varsigma$ and $\mu \alpha \dot{v} \tau \imath \varsigma$ : Georgoudi (1998) 326-35. 
testing of their veracity $(1.47,1.48, c f .2 .29,4.67,4.155)$. The cult of Apollo Ismenios at Thebes was oracular, and the [thes]pistas of this text should of course be understood as the prophet of Apollo, not of Amphiaraus. ${ }^{12}$

Verse 3. The correct restoration of the words following evoóv is not obvious. Assuming that Papazarkadas' reading of lines $4-5$ of Text B is correct, we have the sequence vitot $\alpha$ [..ca. 4..] ]oto (-oio apparently an epic genitive termination). I tentatively suggest restoring $[\mu \alpha] \nu \tau o \sigma v ́ v \alpha 1 \varsigma . . . ~ v ๊ \pi o$ $\tau \underline{\alpha}[\tilde{i} \sigma \iota \theta \varepsilon]$ oĩo, 'by means of oracular consultation of the god', with post-positive $\check{\pi} \pi$.

Verse 4. At the end of the verse, Papazarkadas restores the unaugmented [ $\theta \dot{\varepsilon} \tau o]$, 'erected', but I should prefer to place the verb of dedicating at the end of verse 5, where we can easily restore the standard term [åv $\varepsilon \theta \varepsilon \kappa \varepsilon v]$. Hence I prefer to restore here an epithet describing Amphiaraus: perhaps [ $\theta \varepsilon \tilde{\imath} 1]$, 'god', though it would be awkward to find the term $\theta \varepsilon$ ó $\varsigma$ used of two different deities in verses 3 and $4 .{ }^{13}$ Alternatively, we could conceivably restore the participle [ $\delta 1 \delta$ ó $\zeta$; for the combination $\delta i \delta \omega \mu$... ( $(\dot{\alpha} v \alpha) \tau i ́ \theta \eta \mu$, cf. $C E G 234$ (Athens); $C E G 348$ (Halai).

Verse 5. Papazarkadas' restoration $\mu \nu \tilde{\alpha} \mu$ ' $\alpha \rho \varepsilon \tau\left[\tilde{\alpha}_{\varsigma} \tau \varepsilon \pi \alpha \dot{\alpha} \theta \alpha \varsigma \tau \varepsilon\right]$ derives from Hdt. 1.52, where

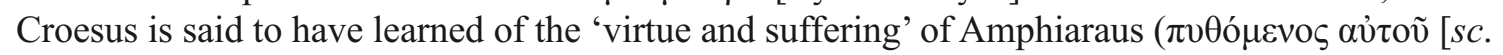

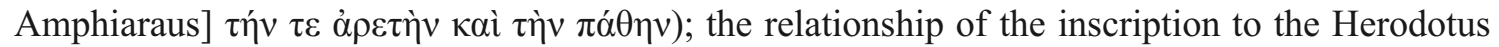
passage is discussed further below. The restored $\tau \varepsilon \ldots \tau \varepsilon$ has parallels in contemporary verse dedi-

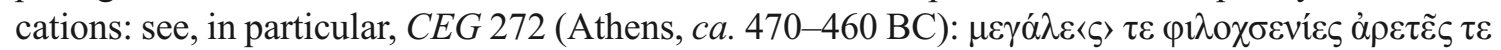

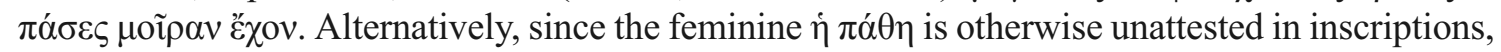

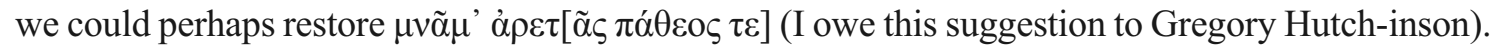

Verses 6-8. These verses are too fragmentary for confident restoration. In verse 6, it is likely enough (as Papazarkadas assumes) that $\dot{\varepsilon} \kappa \lambda \dot{\varepsilon} \varphi \theta \varepsilon$ represents the aorist passive $\dot{\varepsilon}-\kappa \lambda \dot{\varepsilon} \varphi \theta \eta<\kappa \lambda \dot{\varepsilon} \pi \tau \varepsilon v$, 'was stolen'; however, it is conceivable that it could be an unaugmented passive $\dot{\varepsilon} \kappa-\lambda \eta \eta \varphi \eta<$

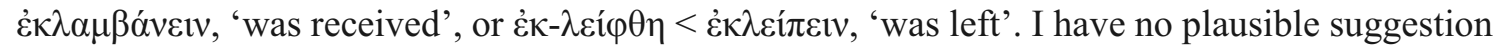

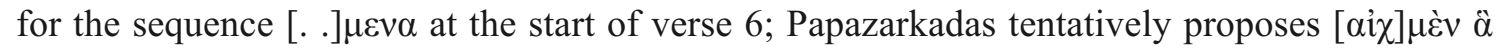
$\dot{\varepsilon} \kappa \lambda \varepsilon \dot{\varepsilon} \varphi \varepsilon$, 'the spear which was stolen', but, as he points out, the lack of a connective is very awkward. I have wondered about [áp] $\mu \varepsilon v \alpha$, 'fittingly' (cf. Pind. Ol. 8.73), but it is hard to make much sense of this in context. In the second half of the verse, $\varphi \circ[--]$ could perhaps be the first syllable of $\varphi \circ[\tau$ ós $]$ or $\varphi \circ[\tau \tilde{v} v]$ (gen.).

As the epigram informs us, in the years around $500 \mathrm{BC}$, an oracular prophet ([thes]pistas) at the Theban sanctuary of Apollo Ismenios 'found' or 'rediscovered' a lost object, which had been dedicated at this (or another) sanctuary some years or decades before (verses 2-3). The object was a 'shining shield', originally given as an offering to the hero Amphiaraus by a man named Croesus (verses 4-5). The prophet located this lost shield 'through divination' - that is, presumably, with the help of the oracle of Apollo Ismenios (verse 3). Exactly what had happened to the shield in the interim is not clear: a badly damaged part of the text (verse 6) includes the verb غ́к $\lambda \dot{\varepsilon} \varphi \theta \varepsilon$ (apparently $\dot{\varepsilon}-\kappa \lambda \dot{\varepsilon} \varphi \theta \eta$, 'was stolen'). The prophet then re-dedicated the shield, this time to the god Apollo, the presiding god of the Theban sanctuary of Apollo Ismenios, accompanied by a new dedicatory epigram in four couplets. The surviving stone is the new base on which the shield was now displayed. Finally, at some point in the fourth century BC, for reasons unknown, the text of the epigram was re-inscribed on the opposite face of the column in Ionic lettering. ${ }^{14}$

12 Oracle of Apollo Ismenios: Hdt. 8.134; Pind. Pyth. 11.6; Schachter (1981) 77-82. The oracular cult of Apollo Ismenios, like that of Apollo Ptoios (Lefèvre (2002) no. 76, 1. 13), seems to have had distinct 'priests' and 'prophets': Georgoudi (1998) 348-51.

13 Amphiaraus is described as a $\theta \varepsilon$ ć $\varsigma$ in several inscriptions from Oropos: see in particular IOropos 329 (third century BC); IOropos 308 (Sherk (1969) no. 23, 73 BC: Amphiaraus a god not a hero).

14 The original re-dedication (in a local Boeotian script) is still perfectly legible today. A. Schachter (quoted by Papazarkadas (2014) 246 n.87) plausibly suggests that the transcription into Ionic script may date to the years of the reconstruction of Thebes (316 to $c a$. 
As Papazarkadas already saw, there can be no serious doubt that this was the very shield seen by Herodotus, in the $440 \mathrm{~s}$ or $430 \mathrm{~s}$, in the sanctuary of Apollo Ismenios at Thebes (1.52). In the new inscription, we have a 'shining shield' (compare Herodotus' 'shield made entirely of gold'), set up by a man named Croesus, dedicated to the hero Amphiaraus, but located in the Temple of Apollo Ismenios. Perhaps most decisive of all is Herodotus' passing remark (1.52) that Croesus dedicated a shield and spear to Amphiaraus 'once he had learned of his virtue and his suffering'

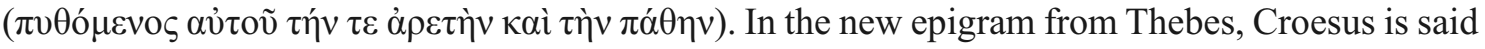
to have dedicated the shield to Amphiaraus as 'a memorial of his virt[ue (and) ...]' ( $\mu v \tilde{\alpha} \mu$ ' $\alpha \rho \varepsilon \tau[\tilde{\alpha} \varsigma$ - -], verse 5). It seems highly likely that Herodotus was here simply copying the wording of the inscription which he saw accompanying Croesus' dedication, and we can confidently restore the fifth verse of the epigram accordingly: 'a memorial of his vir[tue and suffering]' ( $\mu \nu \tilde{\alpha} \mu$ ' $\alpha \rho \varepsilon \tau[\tilde{\alpha} \varsigma$ $\tau \varepsilon \pi \alpha ́ \theta \alpha \varsigma \tau \varepsilon])$.

It is hard to overstate the importance of the new Theban epigram for our understanding of Croesus' relations with Greek oracles. For the first time, we get a sense of the hard evidence on which Herodotus must have based his account of Croesus' testing of the oracles (1.46-56). 'I cannot say what answer the oracle of Amphiaraus gave ... I only know that Croesus also thought that this too was a true oracle' (1.49). All too clearly, Herodotus was willing to draw large inferences from this modest dedication at the sanctuary of Apollo Ismenios.

It is worth emphasizing that the original purpose and context of Croesus' dedication remain a matter of conjecture. We do not know for certain whether the original dedication was accompanied by an inscription at all: it is formally possible that the association of the 'rediscovered' shield with Croesus was a matter of pure guesswork by the thespistas, and that the epigram was composed without reference to any original sixth-century text. Nonetheless, verses $4-5$ of the surviving epigram do look very much like a recasting of an original, two-line dedicatory epigram. ${ }^{15}$

Similarly, the physical form of the 'original' dedication and its base is unknown. The rededication of $c a .500 \mathrm{BC}$ took the form of a poros column, apparently in two drums, serving as a base for the shield, which was probably fixed to an upper moulding or capital. ${ }^{16}$ Columnar dedications of this kind were absolutely standard at the Theban sanctuary of Apollo Ismenios in the sixth and fifth centuries BC: three other columnar dedications to Apollo Ismenios are extant, all of them inscribed on fluted poros column drums. ${ }^{17}$ It is notable that the spear seen by Herodotus does not seem to be mentioned in the extant parts of the epigram; I can offer no explanation for this. ${ }^{18}$

300 BC), when several earlier Theban monuments were re-erected. On the refoundation of Thebes, see now Buraselis (2014).

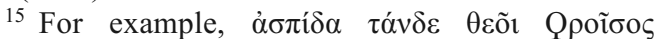

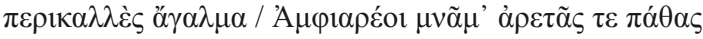
$\tau$ ' $\alpha v \varepsilon \dot{\theta} \theta \kappa \varepsilon v$ (although, as we shall see later on, it is possible that the original dedication was in Attic script and dialect, rather than Boeotian). For Archaic Boeotian votive epigrams in the form of two hexameters, $c f$. Hdt. 5.60-61; CEG 326, 335.

16 Papazarkadas (2014) 236.

17 Columnar dedications to Apollo Ismenios: (1) SEG 22.417 (Lazzarini (1976) no. 903: Thebes, near the

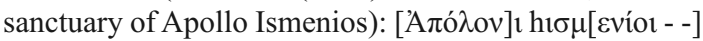

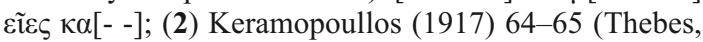

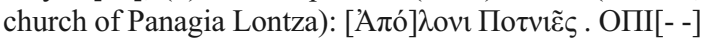
ONIKETAO . IKA . $\Delta[-$ - ]; (3) Aravantinos (2014) 206-

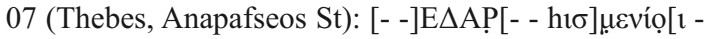
-]. Four further dedications naming Apollo Ismenios are known: (4) $I G$ VII 2455 (Lazzarini (1976) no. 118:

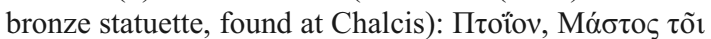

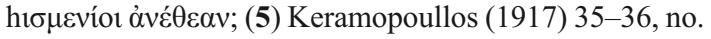
1 (Lazzarini (1976) no. 116: bronze oinochoe, Thebes, sanctuary of Apollo Ismenios): По $\lambda \hat{v} \kappa \lambda \varepsilon \tau \mathrm{o}[\varsigma] \alpha \dot{\alpha} v \varepsilon \varepsilon \kappa \varepsilon$

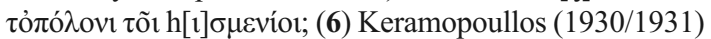
(Lazzarini (1976) no. 916: rectangular base, Thebes, chapel of Metamorphosis tou Soteros): [A $\pi$ ónovi]

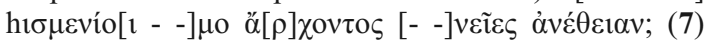
Aravantinos (2014) 202-04 (bronze kantharos, Theban

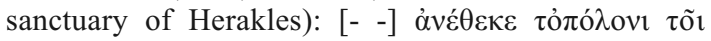
$\mathrm{h}[1 \sigma \mu \varepsilon v i ́ o 1]$.

18 Papazarkadas ((2014) 244) tentatively restores the Ionic form $[\alpha i \chi] \mu \varepsilon ́ v$ at the start of verse 6; but, as noted above, the absence of a connective is problematic. 


\section{Herodotus at the sanctuary of Apollo Ismenios}

As the new inscription makes clear, Croesus' dedication to Amphiaraus had made its way to the Theban sanctuary of Apollo Ismenios by $c a .500 \mathrm{BC}$ at the latest. Where the dedication was originally located depends on the long-standing question of whether or not there was an oracular sanctuary of Amphiaraus at Thebes in the sixth and fifth centuries BC, a problem which the new inscription does little to illuminate. ${ }^{19}$ From at least the late fifth century onwards, the sole oracular sanctuary of Amphiaraus in Boeotia was situated at Oropos, in the coastal region dividing northeast Attica from southeast Boeotia. However, there seems to be no archaeological evidence for this sanctuary before the mid fifth century BC. Both Aeschylus and Herodotus clearly imply the existence of an oracle of Amphiaraus at Thebes in the early fifth century, and Strabo preserves the tradition that the oracle of Amphiaraus was transferred to Oropos (at an uncertain date) from an unidentified place called Knopia, apparently at or near Thebes. ${ }^{20}$ It is possible, therefore, that the oracular cult of Amphiaraus was transferred from Thebes to Oropos in the third quarter of the fifth century. However, we cannot be certain that Croesus' dedication to Amphiaraus was originally located at Thebes; it is quite possible, for instance, that the dedication was originally made at Oropos, and that Croesus' shield and spear were plundered from the sanctuary (along with other valuables) by the Thebans at some point in the later sixth century. ${ }^{21}$ It is conceivable that the fragmentary final three verses of our epigram would have shed light on the question.

At any rate, the new inscription renders it quite certain - if there was ever any doubt - that Herodotus did indeed visit the Theban sanctuary of Apollo Ismenios, probably some time in the $440 \mathrm{~s}$ or $430 \mathrm{~s} \mathrm{BC}$, and inspected the various inscribed monuments dedicated there. ${ }^{22}$ The Theban sanctuary of Apollo Ismenios is securely located, on a small hill $200 \mathrm{~m}$ east of the southeastern tip of the Kadmeia. The cult building that Herodotus saw (and which housed Croesus' dedication to Amphiaraus) was a temple of poros stone, apparently built around $700 \mathrm{BC}$; this building continued in use until the early fourth century, when it was replaced by a larger Doric peripteral temple. ${ }^{23}$

Aside from Croesus' dedication to Amphiaraus, Herodotus mentions four further monuments from the sanctuary of Apollo Ismenios, all of which took the form of tripod-dedications. First, Croesus himself is said to have dedicated a golden tripod to Apollo Ismenios (1.92.1), recalling Pindar's description of the sanctuary of Apollo Ismenios as an 'inviolate treasury of golden tripods'

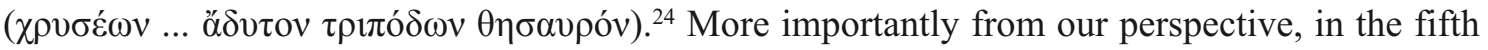
book of his Histories, Herodotus gives a detailed account of three inscribed tripod-dedications at the sanctuary (5.59-61). ${ }^{25}$ In each case, the inscription is said to have been incised on the tripod itself (rather than on their stone bases, if they had them).

The first inscription quoted by Herodotus clearly refers to a figure from Greek mythology. It purports to be a dedication of Heracles' father Amphitryon, erected on his return from the land of the Teleboeans (5.59): 'Amphitryon dedicated me [...] from the Teleboeans' ('A $\mu \varphi \imath \tau v ́ \omega v \mu$ '

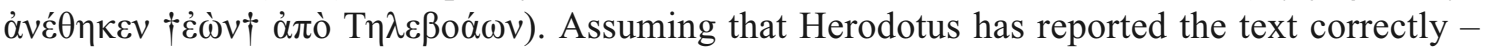

19 See in particular Schachter (1981) 21-23 (negative); Hubbard (1992) 101-07 (positive); Parker (1996) 146-49 (cautiously positive).

20 Aesch. Sept. 587-88: ह̌ $\gamma \omega \gamma \varepsilon$ [sc. Amphiaraus] $\mu$ غ̀े

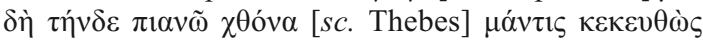

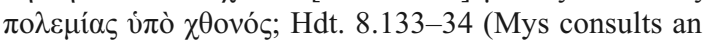
oracle of Amphiaraus at Thebes). Transferral from Knopia to Oropos: Strabo 9.2.10. The death of the seer Amphiaraus at Thebes was traditional: Hom. Od. 15.244-47; cf. Pind. Pyth. 8.39-56 (Amphiaraus prophesies at Thebes).

21 Schachter (1981) 22.

22 Questioned by West (1985) 289-95.
23 Archaeology of the sanctuary: Keramopoullos (1917) 33-79; Symeonoglou (1985) 236-39. Mythical aetiology: Kowalzig (2007) 371-82. A new joint GreekAmerican excavation of the site began in 2011, conducted by a team from Bucknell University, in collaboration with the Ninth Ephorate of Prehistoric and Classical Antiquities and the 23rd Ephorate of Byzantine Antiquities.

${ }_{24}$ Pind. Pyth. 11.4-5; with Finglass (2007) 78-79.

25 Fehling (1989) 138-40; Pritchett (1993) 116-21; Papalexandrou (2008) 256-59; Hornblower (2013) 17981. 
which we have no good reason to question - then this inscription must certainly be a fictive composition of the seventh, sixth or early fifth century BC, added to an anonymous tripod-dedication by the sanctuary personnel in order to give the monument a spurious patina of heroic antiquity. ${ }^{26}$

The second tripod-inscription recorded by Herodotus is considerably more interesting (5.60).

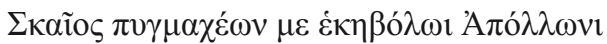

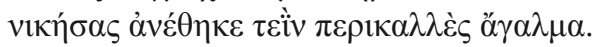

Skaios, having been victorious in boxing, dedicated me to you, far-shooting Apollo, as a most beautiful ornament.

Herodotus goes on to remark that 'Skaios would be the son of Hippocöon, a contemporary of Oedipus son of Laius - if the dedicator was indeed that Skaios, and not another man bearing the same name as Hippocöon's son'. Herodotus' doubts about the identification of Skaios with the (obscure) mythological son of Hippocöon are surely well-placed. ${ }^{27}$ This tripod is far more likely to have been an authentic seventh- or sixth-century victory-dedication, erected by a boxer with the self-explanatory nickname Skaios, 'Southpaw' (i.e. 'left-handed'). ${ }^{28}$ Given Herodotus' own doubts on the matter, it was probably Herodotus' Theban guides (the sacred officials of the sanctuary of Apollo Ismenios) who were responsible for misinterpreting this tripod as a relic of the heroic age. As we will see later on, this may not have been the only dedication in the sanctuary of Apollo Ismenios to have suffered from a case of mistaken identity.

The third tripod-inscription - a pair of hexameters, like the dedication of Skaios - is no less suggestive. It purports to be a dedication of the legendary Laodamas, son of Eteocles, set up 'while he was mounarchos' (5.61).

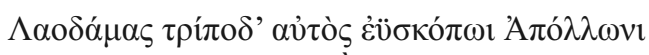

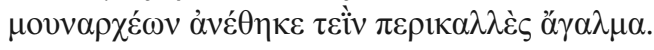

Laodamas himself, while he was mounarchos, dedicated the tripod to you, keen-eyed Apollo, as a most beautiful ornament.

This (fictive) dedicatory inscription seems fairly clearly to have been modelled on the (authentic) dedicatory inscription of Skaios the boxer. The two texts are identical in their structure, and most of the second verse of the Laodamas epigram has been taken over wholesale from the Skaios epigram. ${ }^{29}$ In creating this bogus epigraphic 'label' for a supposed dedication of the hero Laodamas, the Theban sanctuary personnel seem to have followed a perfectly rational procedure: pick the oldest-looking dedication in the sanctuary, and copy its form and content as closely as possible. ${ }^{30}$

\footnotetext{
${ }^{26}$ I leave on one side the complicated relationship between the tripod-dedication of Amphitryon recorded by Herodotus, the tripod-dedication of Amphitryon seen at the same sanctuary by Pausanias 600 years later (9.10.4) and the tripod-dedication of Amphitryon depicted on the Tabula Albani (IG XIV 1293b $=F G r H$ 40(b), p. 263). See Schachter (2000) 114-16; Finglass (2007) 28; Papalexandrou (2008) 257-58.

27 Papalexandrou ((2008) 259) describes the mythological Skaios as 'otherwise unattested', but $c f$. Apollod. Bibl. 3.10.5. His name may have appeared in a fragmentary part of Alcman's Partheneion (Page (1951) 26-30).

28 'Skaios' = 'Southpaw': Hornblower (2013) 180 (a
}

brilliant suggestion)

29 The Laodamas epigram is in fact a rather shoddy composition: note the superfluous $\tau \rho i \operatorname{ro} \delta(\alpha)$ in verse 1 , the space-filler $\alpha$ vó $\varsigma_{\text {in }}$ the same verse and the unnecessarily emphatic $\mu$ ovv $\alpha \rho \chi \varepsilon \dot{\varepsilon} \omega v$ in verse 2 (underlining the heroic status of the dedicator).

${ }^{30}$ For conscious epigraphic forgeries of this kind, compare Chaniotis (1999) 61-64, a fictive Archaic decree of the Cretan koinon at Magnesia on the Maeander (IMagn. 20), closely modelled on authentic decrees of Cretan cities; also Chaniotis (1988) 267-71 (Lindian chronicle). Note also Hdt. 1.51.3-4 (spurious Lacedaemonian inscription at Delphi). 
In none of these three cases is there any real reason to doubt that Herodotus saw the inscriptions that he claims to have seen. In the cases of the dedications of Amphitryon and Laodamas, he interprets their intended meanings correctly, and he seems to suspect the true (non-heroic) character of the dedication of Skaios the boxer. The three monuments, as reported by Herodotus, offer us a fascinating glimpse of an intelligent and creative group of sanctuary personnel at work, first overinterpreting an ordinary Archaic agonistic dedication (the Skaios epigram) as a relic of the age of Oedipus and then crafting a spurious dedication of another legendary hero (Laodamas) on the model of this misunderstood text. This, one is tempted to say, was a sanctuary which really understood the importance of early Greek epigraphy. ${ }^{31}$

\section{The wrong Croesus?}

As I have argued above, it seems to me quite certain (as Papazarkadas has already argued) that the new inscription from Thebes is the very stone seen by Herodotus in the mid fifth century BC and that this epigram is the basis for all that Herodotus tells us about the consultation of the oracle of Amphiaraus by the Lydian king Croesus. However, that is not to say that Herodotus' interpretation of the text is necessarily the right one. It is far from clear that Croesus' dedication to Amphiaraus had anything to do with Croesus' testing of the Delphic Oracle (and others). As Herodotus himself acknowledges:

I cannot say what answer the oracle of Amphiaraus gave to the Lydians once they had performed the traditional rites at the sanctuary, for there is no record of it; I only know that Croesus also thought that this too was a truthful oracle. (1.49, my emphasis)

Reading between the lines, we may guess that all Herodotus knew for certain was that Croesus had offered a dedication to the oracular Amphiaraus. He thereby inferred (a) that Croesus thought that the oracle of Amphiaraus was a truthful one and (b) that Croesus had established this at the time of his 'testing' of the Delphic Oracle. We have no reason to follow Herodotus in this second assumption.

But this is not the only problem with Herodotus' reading of the Theban dedication. Herodotus says (1.52) that Croesus dedicated a golden spear and shield to Amphiaraus 'once he had learned

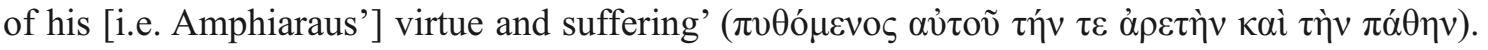
This is, it seems to me, something of a non sequitur. In Greek mythology, the hero Amphiaraus did indeed die a virtuous death (during the war of the Seven against Thebes), but it is hard to see why his 'virtue and suffering' should have mattered to Croesus one way or the other. Croesus was interested in Amphiaraus' oracular capacities, not his life-story.

In fact, we can now be all but certain that Herodotus' statement about Croesus' motives for his dedication is drawn directly from the wording of the extant epigram, in which Croesus is said to have dedicated the shield 'as a memorial of his virtue and suffering' ( $\mu v \tilde{\alpha} \mu$ ' $\alpha \rho \varepsilon \tau[\tilde{\alpha} \varsigma \tau \varepsilon \pi \alpha$ á $\theta \varsigma \tau$ ' $\grave{\alpha} v \varepsilon \dot{\theta} \theta \varepsilon \kappa \varepsilon v])$. Herodotus clearly understood this phrase as referring to Amphiaraus' own virtue and suffering, and extrapolated accordingly. But this interpretation is almost certainly incorrect. When people in the Archaic Greek world set up dedications 'as a memorial of such-and-such', the phrase invariably refers to an event in their own lives, not in the life of the god or hero to whom they are

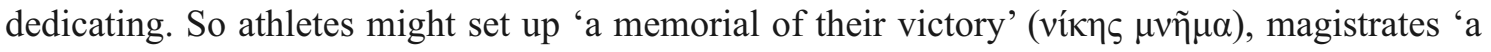
memorial of their office' ( $\dot{\alpha} \rho \tilde{\eta} \varsigma \mu v \tilde{\eta} \mu \alpha)$ and so forth. ${ }^{32}$

31 For the epigraphic expertise of the officials at the sanctuary of Apollo Ismenios - and the sanctuary's reputation as a storehouse of early Greek inscriptions - see Arist. [Mir. ausc.] 843b-44a; with Huxley (1967).

32 'Memorial of victory': CEG 376 (Laconia, ca.

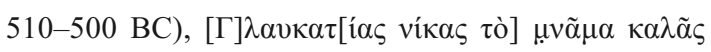
$\dot{\alpha}[v \varepsilon \dot{\theta} \theta \varepsilon \kappa \varepsilon]$. 'Memorial of office': Thuc. 6.54.7 (Meiggs and Lewis (1988) no. 6; CEG 305: Athens, 522/1 BC),

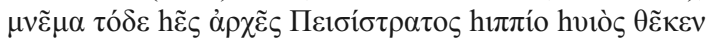

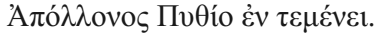


So what would it mean for a man to set up a shield and spear as 'a memorial of his (own) virtue and suffering'? To my mind, the most natural interpretation is that the monument commemorates Croesus' own 'virtue and suffering' in warfare. In Archaic and Classical votive and funerary epigrams, the term arete is regularly used of martial virtue and particularly of the virtue of men who have died in war. ${ }^{33}$ So the funerary monument erected by the Parians for a Thracian called Tokes, who died in battle at Eion in the late sixth century, is described as a 'memorial of his virtue' ( $\mu v \tilde{\eta} \mu$ ' $\dot{\rho} \rho \varepsilon \tau \tilde{\eta} \varsigma)$ and an Athenian casualty list, perhaps dating to $447 \mathrm{BC}$, was erected as 'an immortal memorial of their virtue' ( $\dot{\alpha} \theta \alpha \dot{\alpha} \alpha \tau \tau \nu \mu v \tilde{\varepsilon} \mu$ ' $\dot{\alpha} \rho \varepsilon \tilde{\varepsilon} \varsigma) .{ }^{34}$ The terms pathe and pathos seem not to be attested elsewhere in Archaic and Classical epigrams, but could easily refer to the dedicant's 'suffering' or 'death' in battle. ${ }^{35}$ A votive dedication set up as 'a memorial of (the dedicant's) virtue and suffering' ought therefore to be taken as a post mortem memorial of the dedicant's own valiant death in battle - actually set up, of course, by his family or descendants.

This interpretation would also help to make sense of the particular objects offered by Croesus to Amphiaraus: a shield and a spear (the latter only attested by Herodotus and apparently not mentioned in the surviving epigram). Greek warriors often celebrated their own martial exploits by dedicating their own used shields, spears and other kinds of armour and weapons. ${ }^{36}$ Men who had died gloriously in battle could be commemorated in the same way: for example, the relatives of Kydias the Athenian, who died during the defence of Delphi against the Galatians in 279 BC, subsequently dedicated the dead man's shield to Zeus Eleutherios. ${ }^{37}$

Of course, no-one would ever have carried a golden shield and spear into battle. But it is quite possible that the shield dedicated by Croesus, and seen by Herodotus in the sanctuary of Apollo Ismenios, was not in fact made of solid gold. Herodotus explicitly says that the shield and spear

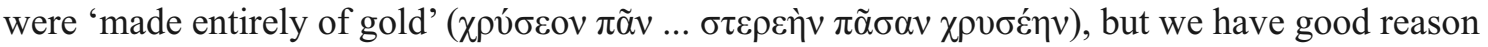
to think that he elsewhere mistook gilded bronze dedications for solid gold. ${ }^{38}$ Dedications of gilded bronze weapons are perfectly common in later periods: to take only a single example, a gilded bronze shield ( $\dot{\alpha} \sigma \pi i \zeta \dot{\varepsilon} \pi \dot{x} \chi \rho v \sigma o \zeta)$ dedicated by the Athenian general Iphicrates is recorded in two late fourth-century inventories from the Athenian Acropolis. ${ }^{39}$

More seriously, it is prima facie surprising that a dedicant could be described as setting up a monument after his own death. 'Dead men', as R. Meiggs and D.M. Lewis once wrote in a similar context, 'do not make dedications'. ${ }^{40}$ But in fact, in the Greek world of the sixth and fifth centuries $\mathrm{BC}$, dead men did on occasion do precisely that. The best-known example is the lavish monument on the Athenian Acropolis commemorating the polemarch Callimachus, who died heroically during the Battle of Marathon in $490 \mathrm{BC}$. The columnar base of the Callimachus monument carried an epigram in five verses, inscribed in two long lines along the length of the column: ${ }^{41}$

33 Arete in Herodotus usually refers to military valour: Immerwahr (1966) 308-09.

${ }^{34}$ Epitaph of Tokes (late sixth century BC): $S E G$ 27.249 (CEG 155). Athenian casualty list (?447 BC):

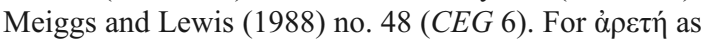
a euphemism for death in battle, $c f$. also, for example, the new Marathon casualty list: SEG 56.430 (490 BC), $\tau \tilde{\nu} v \delta$ '

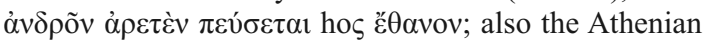
epigram on the Persian wars: Meiggs and Lewis (1988)

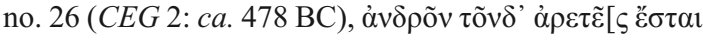

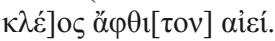

${ }^{35}$ The verb $\pi \alpha \dot{\sigma} \chi \varepsilon ı v$ is twice used of 'dying' in fifthcentury verse epitaphs: $C E G 163$ (Thera, ca. 500 BC),

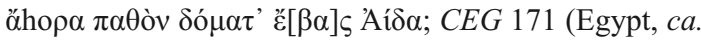

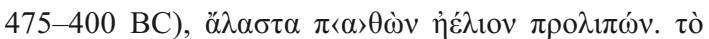
$\pi \alpha \dot{\theta} \theta \mathrm{o}_{\text {in }}$ in Herodotus can carry the sense of 'death': for example 2.133 .

${ }^{36}$ Pritchett (1979) 240-76.

37 Paus. 10.21.5.

38 Griffith (1988), showing that the 'gold' krater dedicated by Croesus at Delphi (1.51.1-4) must in fact have been of gilded bronze; thus also Kosmetatou (2013) 73.

${ }^{39} I G \mathrm{II}^{2} 1487.39-40,1489.5-6$.

40 Meiggs and Lewis (1988) 33.

${ }^{41} I G \mathrm{I}^{3} 784 ; C E G 256$ (the text followed here); with Keesling (2010). 


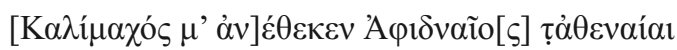

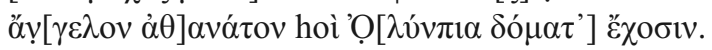

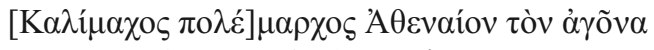

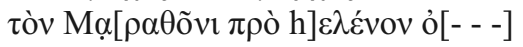

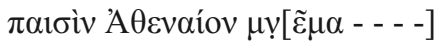

[Callimachus] of Aphidna [ded]icated [me] to Athena, me[ssenger of the im]mortals who dwell on O[lympus]. [Callimachus, pole]march of the Athenians, [...] the battle at Ma[rathon on behalf of the G]reeks, [...] the sons of the Athenians, a mem[orial ...]

As Catherine Keesling has recently shown, this entire dedicatory text - whether or not we formally divide it into two separate epigrams - was certainly inscribed after Callimachus' death at Marathon. It is likely enough that Callimachus had made a vow of some kind to Athena before the battle, but the actual dedication was performed and paid for by Callimachus' relatives or (more

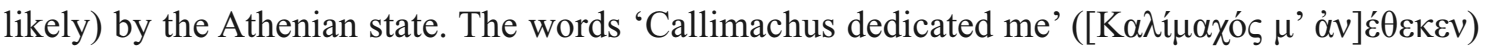
ought thus not to be taken au pied de la lettre: as Keesling puts it, 'The conceptual leap from the first person speech of the deceased in some grave epigrams to the naming of a dead man as dedicator with $\alpha v \alpha \tau i \theta \eta \mu \mathrm{r}$ may not have been as great as we tend to think' ${ }^{42}$

I know of two further probable examples of post mortem dedications of this kind, although admittedly neither case is quite as certain as that of the polemarch Callimachus. The first is a votive monument to Athena from the Athenian Acropolis, dated ca. 470-460 BC. The text reads as follows:

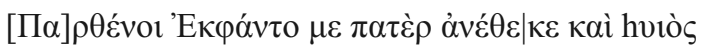

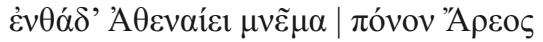

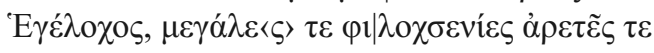

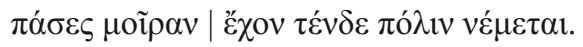

Hegelochos, father and son of Ekphantos, dedicated this memorial of his toils in war to the maiden Athena. Having a share of great hospitality and all virtue, he resides in this city. ${ }^{43}$

If Hegelochos were still living at the time of the monument's dedication, the final phrase of his

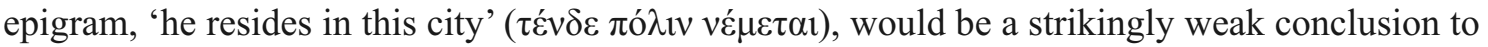
the text. ${ }^{44}$ It is, to my mind, more likely that the phrase signifies that Hegelochos - apparently a non-Athenian - was buried at Athens, and hence now 'resides' there in perpetuity, having died in the course of his 'toils in war' ( $\pi$ óvov 'A $\rho \varepsilon o \varsigma)$.

The second example derives from Olympia, where, around 460 BC, a certain Praxiteles dedicated a bronze statue-group, accompanied by the following epigram:

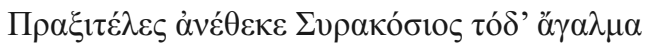

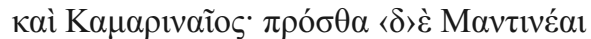

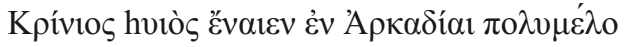

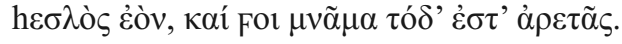

Praxiteles, citizen of Syracuse and Kamarina, dedicated this statue; he, the son of Krinis, used formerly to dwell in Mantinea, in Arkadia of many sheep, being a good man - and for him this is a memorial of his virtue. ${ }^{45}$

42 Keesling (2010) 113-19. Olympic victor-dedications naming the victors as dedicators seem often to have been erected after the dedicant's death: Amandry (1957).

${ }^{43} I G \mathrm{I}^{3}$ 850; CEG 272; Keesling (2003) 186-90.

\footnotetext{
44 'A rather bland description of his Athenian domicile' (Bowie (2010) 350).

45 CEG 380; with Bowie (2010) 346-47.
} 
As L.H. Jeffery already remarked, the final line makes it very likely that Praxiteles was dead at the time the monument was inscribed. The location of the statue-group at Olympia may suggest that he was an athlete, although it is possible that Praxiteles too died in war. ${ }^{46}$

If it is indeed the case that the Croesus-monument from Thebes was set up as a post mortem dedication after the dedicant's death in war, it comes to seem rather unlikely that the dedicant was Croesus the Lydian king. We should therefore consider the possibility that the dedicant was another, homonymous Croesus - perhaps a Greek, rather than a foreigner (the extant epigram does not give Croesus a title or an ethnic) - who died in battle at some point in the mid to late sixth century BC.

And as it happens, we do know of another Croesus, who fell in battle at about the right date. Around 530-520 BC, a young Athenian called Croesus was commemorated at Anavyssos in Attica with a fine marble kouros, accompanied by a short funerary epigram:

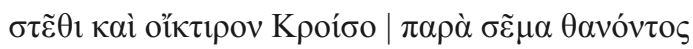

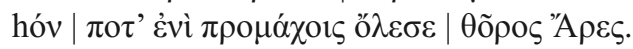

Stand and take pity beside the tomb of the dead Croesus, whom wild Ares once slew in the front rank. ${ }^{47}$

This Greek warrior Croesus - no doubt named after the famous Lydian king - must have belonged to one of the wealthiest families in sixth-century Athens. Indeed, it is likely enough that he belonged to the family of the Alcmaeonids; he may have been the son of the Alcmaeon who, as Herodotus tells us (6.125), had been guest-friend to the Lydian Croesus in the mid sixth century. ${ }^{48}$ At any rate, the family of the Athenian Croesus could certainly have afforded to set up a lavish memorial to his 'virtue and suffering' at the nearby Boeotian sanctuary of Amphiaraus (whether this sanctuary was in fact located at Oropos or at Thebes). There would be nothing surprising about an Alcmaeonid dedication at a Boeotian oracular sanctuary; as Herodotus himself tells us (8.134), the oracle of Amphiaraus was reserved for non-Thebans, and two further Athenian private votive monuments of the mid sixth century have been found at the Boeotian sanctuary of Apollo Ptoieus: one dedicated by Hipparchus, the other by Alcmaeonides son of Alcmaeon (perhaps Croesus' brother). ${ }^{49}$

I would like to suggest that Herodotus - or more likely his Theban guides - misinterpreted a dedication of (or on behalf of) the Athenian Croesus as an offering of the famous Lydian king

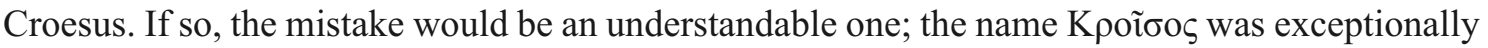
rare (we do not know of another Greek example before the later fifth century) and a dedication in the name of 'Croesus' would most naturally have been taken as referring to the Lydian king. ${ }^{50}$ Crucially, we know that this is the kind of mistake to which Herodotus' guides at the sanctuary of Apollo Ismenios were particularly prone. As we have already seen, in the mid fifth century, an Archaic tripod-dedication erected by a certain 'Skaios the boxer' was still to be seen at the sanctuary of Apollo Ismenios. The temple personnel tried to persuade Herodotus that this was a dedication of the mythological Skaios, "the son of Hippocöon, a contemporary of Oedipus son of Laius', but Herodotus himself suspected - surely correctly - that the dedicant was more likely to

46 Jeffery (1990) 211 n.3; thus also Hansen in the lemma to $C E G 380$.

$47 I G \mathrm{I}^{3} 1240 ; C E G 27$.

${ }^{48}$ For the identification of the Kpoĩoos of CEG 27 as an Alcmaeonid, see Jeffery (1962) 144 (son of Alcmaeon); Eliot (1967) 280-84 (son of Megacles); Davies (1971) 374 (cautious). The name [Kроĩ ]ọ has accordingly been restored in a mid-sixth-century Alcmaeonid athletic dedication from the Athenian Acropolis: $I G \mathrm{I}^{3} 597$.
49 Hipparchus: $I G \mathrm{I}^{3}$ 1470; Alcmaeonides: $I G \mathrm{I}^{3} 1469$ (CEG 302); Schachter (1994). Neither monument indicates the dedicator's Athenian origin.

${ }^{50}$ In pre-Hellenistic periods, aside from the Lydian king and the sixth-century Athenian from Anavyssos, the

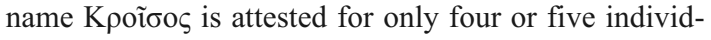
uals, all resident at Athens: LGPN II s.v.; Osborne (2011) 110 . 
have been an obscure later homonym (5.60). The dedication of 'Croesus' could easily have been subjected to exactly the same kind of optimistic over-interpretation. ${ }^{51}$

It is unclear whether the anonymous Theban thespistas who re-dedicated Croesus' shield in the years around $500 \mathrm{BC}$ had already misinterpreted the dedication in this way. The most we can say is that by the 440s or 430s, when Herodotus visited the sanctuary of Apollo Ismenios, the true identity of 'Croesus' had been forgotten. Herodotus' whole story of the Lydian king Croesus' consultation of the oracle of Amphiaraus should, I suggest be seen as little more than imaginative guesswork, spun out from this single, misunderstood monument.

\section{Conclusion}

In the end, as we have seen, the new dedication of 'Croesus' from the sanctuary of Apollo Ismenios sheds somewhat less light on the reign of King Croesus of Lydia than we might have hoped. On the contrary, we have been given one more reason to be suspicious of both the general shape and the particular details of Herodotus' account of Croesus' relations with Greek oracles.

Nonetheless, we ought not to be ungrateful; on any hypothesis, the new epigram is quite remarkable enough. Only very seldom are we in a position to check Herodotus' narrative against the primary source that he himself utilized. And if my discussion in section IV of this paper is on the right lines, then we can be pretty sure that we have caught out Herodotus in a bit of wishful thinking. I have argued that Herodotus (or his Theban guides) mistook a relatively obscure Athenian Croesus for the famous Croesus of Lydia. As a result, this unusually lavish private Athenian votive dedication from the Theban sanctuary of Apollo Ismenios ended up being used by Herodotus - incorrectly, albeit no doubt in good faith - as evidence for King Croesus' relations with Greek oracles. For the first time, thanks to the new inscription from Thebes, we know for certain how Herodotus put together part of his narrative of Croesus' reign; we can be pretty certain that this particular stretch of Herodotean narrative (the 'testing' of the oracle of Amphiaraus) rests on sand, if not on air. And so that elusive figure, the historical King Croesus of Lydia, slips ever further away from us, into the shadows of myth.

\section{Bibliography}

Amandry, P. (1957) 'A propos de Polyclète: statues d'Olympioniques et carrière de sculpteurs', in K. Schauenburg (ed.), Charites: Studien zur Altertumswissenschaft (Bonn) 63-87

Aravantinos, V.L. (2014) 'The inscriptions from the sanctuary of Herakles at Thebes: an overview', in N. Papazarkadas (ed.), The Epigraphy and History of Boeotia: New Finds, New Prospects (Leiden and Boston) 149-210

Asheri D., Lloyd, A. and Corcella, A. (ed. O. Murray and A. Moreno) (2007) A Commentary on Herodotus: Books I-IV (Oxford)

Bonnechere, P. (2010) 'Oracles and Greek mentalities: the mantic confirmation of mantic revelations', in J. Dijkstra, J. Kroesen and Y. Kuiper (eds), Myths, Martyrs, and Modernity: Studies in the History of Religions in Honour of Jan N. Bremmer (Leiden and Boston) 115-33

Bowie, E. (2010) 'Epigram as narration', in M. Baumbach, A. Petrovic and I. Petrovic (eds), Archaic and Classical Greek Epigram (Cambridge) 313-84

Buraselis, K. (2014) 'Contributions to rebuilding Thebes: the old and a new fragment of $I G$ VII $2419=$ Sylloge 337 ', ZPE 188, 159-70

51 For analogous instances of obscure dedicants being reinterpreted as famous figures from the Greek past, see Prêtre (2003) 97-100 (Hellenistic Delian inventories: Patesis becomes Datis, Ameinondas becomes Epameinondas). 
Cahill, N.D. (2010) 'Sardeis’te Pers Tahribi/The Persian sack of Sardis', in N.D. Cahill (ed.), Lidyalılar ve Dünyalarl/The Lydians and Their World (Istanbul) 339-61

Chaniotis, A. (1988) Historie und Historiker in den griechischen Inschriften (Stuttgart)

- (1999) 'Empfängerformular und Urkundenfälschung: Bermerkungen zum Urkundendossier von Magnesia am Mäander', in R.G. Khoury (ed.), Urkunden und Urkundenformulare im Klassischen Altertum und in den orientalischen Kulturen (Heidelberg) 51-69

Christ, M.R. (1994) 'Herodotean kings and historical enquiry', ClAnt 13, 167-202

Davies, J.K. (1971) Athenian Propertied Families, 600-300 BC (Oxford)

Eliot, C.W.T. (1967) 'Where did the Alkmaionidai live?', Historia 16, 279-86

Fabiani, R. (2003) 'Epigrafi in Erodoto', in A.M. Biraschi, P. Desideri, S. Roda and G. Zecchini (eds), L'uso dei documenti nella storiografia antica (Naples) 162-85

Fehling, D. (tr. J.G. Howie) (1989) Herodotus and his Sources. Citation, Invention and Narrative Art (Leeds)

Finglass, P.J. (2007) Pindar: Pythian Eleven (Cambridge)

Flower, H.I. (1991) 'Herodotus and Delphic traditions about Croesus', in M.A. Flower and M. Toher (eds), Georgica: Greek Studies in Honour of George Cawkwell (BICS Supplement 58) (London) 57-77

Georgoudi, S. (1998) 'Les porte-parole des dieux: réflexions sur le personnel des oracles grecs', in I. Chirassi Colombo and T. Seppilli (eds), Sibille e linguaggi oraculari: mito, storia, tradizione (Pisa and Rome) $315-65$

Griffith, J.G. (1988) 'Two passages from Herodotus and the bronze crater from the royal tomb at Vix-surSeine (Châtillonnais)', in Festinat Senex (Oxford) 5-23

Hellmann, F. (1934) Herodots Kroisos-Logos (Berlin)

Hornblower, S. (2013) Herodotus: Histories V (Cambridge)

Hubbard, T.K. (1992) 'Remaking myth and rewriting history: cult tradition in Pindar's ninth Nemean', HSPh $94,77-111$

Huxley, G. (1967) 'A poem of the Ainianes', GRBS 8, 88-92

Immerwahr, H.R. (1966) Form and Thought in Herodotus (Chapel Hill)

Jeffery, L.H. (1962) 'The inscribed gravestones of Archaic Attica', ABSA 57, 115-53

- (1990) The Local Scripts of Archaic Greece (revised edition with a supplement by A.W. Johnston) (Oxford)

Keesling, C.M. (2003) The Votive Statues of the Athenian Acropolis (Cambridge)

- (2010) 'The Callimachus monument on the Athenian Acropolis (CEG 256) and Athenian commemoration of the Persian wars', in M. Baumbach, A. Petrovic and I. Petrovic (eds), Archaic and Classical Greek Epigram (Cambridge) 100-30

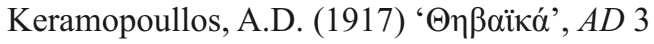

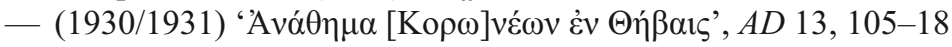

Kerschner, M. (2006) 'Lydische Weihungen in griechischen Heiligtümern', in A. Naso (ed.), Stranieri e non cittadini nei santuari greci (Florence) 253-91

Kosmetatou, E. (2013) 'Herodotus and temple inventories', in P. Liddel and P. Low (eds), Inscriptions and their Uses in Greek and Latin Literature (Oxford) 65-77

Kowalzig, B. (2007) Singing for the Gods: Performances of Myth and Ritual in Archaic and Classical Greece (Oxford)

Lazzarini, M.L. (1976) Le formule delle dediche votive nella Grecia arcaica (Rome)

Lefèvre, F. (2002) Corpus des inscriptions de Delphes IV. Documents amphictioniques (Athens)

Meiggs, R. and Lewis, D. (1988) A Selection of Greek Historical Inscriptions to the End of the Fifth Century $B C$ (revised edition) (Oxford)

Mills, S.J.V. (2014) 'The Lydian logos of Herodotus 1.50-2', G\&R 61, 147-51

Osborne, R. (2011) The History Written on the Classical Greek Body (Cambridge)

Page, D.L. (1951) Alcman: The Partheneion (Oxford)

Papalexandrou, N. (2008) 'Boiotian tripods: the tenacity of a Panhellenic symbol in a regional context', Hesperia 77, 251-82

Papazarkadas, N. (2014) 'Two new epigrams from Thebes', in N. Papazarkadas (ed.), The Epigraphy and History of Boeotia: New Finds, New Prospects (Leiden and Boston) 223-51

Parker, R. (1996) Athenian Religion: A History (Oxford)

Prêtre, C. (2003) ' «Erreurs» de gravure involuntaires et voluntaires dans les inventaires: de la création d'hapax à l'usurpation d'identité', Tekmeria $8,85-101$ 
Pritchett, W.K. (1979) The Greek State at War III. Religion (Berkeley, Los Angeles and London)

- (1993) The Liar School of Herodotos (Amsterdam)

Rollinger, R. (2008) 'The Median “empire”, the end of Urartu and Cyrus the Great's campaign in 547 BC (Nabonidus Chronicle II 16)', Ancient West \& East 7, 51-65

Schachter, A. (1981) Cults of Boiotia 1. Acheloos to Hera (London)

- (1994) 'The politics of dedication: two Athenian dedications at the sanctuary of Apollo Ptoieus in Boeotia', in R. Osborne and S. Hornblower (eds), Ritual, Finance, Politics: Athenian Democratic Accounts Presented to David Lewis (Oxford) 291-306

- (2000) 'The Daphnephoria of Thebes', in P.A. Bernardini (eds.), Presenza e funzione della città di Tebe nella cultura greca (Pisa and Rome) 99-123

Sherk, R.K. (1969) Roman Documents from the Greek East (Baltimore)

Symeonoglou, S. (1985) The Topography of Thebes from the Bronze Age to Modern Times (Princeton)

van der Spek, R.J. (2014) 'Cyrus the Great, exiles, and foreign gods: a comparison of Assyrian and Persian policies on subject nations', in M. Kozuh, W.F.M. Henkelman, C.E. Jones and C. Woods (eds), Extraction \& Control: Studies in Honor of Matthew W. Stolper (Chicago) 233-64

Wallace, R.W. (2016) 'Redating Croesus: Herodotean chronologies, and the dates of the earliest coinages', JHS 136, 168-81

West, S. (1985) 'Herodotus' epigraphical interests', CQ 38, 278-305 